\title{
PEMANFAATAN TANAH MEDITERANIAN SEBAGAI MEDIA PEMBIBITAN BUDSET TEBU (Saccharum officinarum L.) VARIETAS BULULAWANG DENGAN PENAMBAHAN PUPUK KANDANG PADA DOSIS YANG BERBEDA
}

\section{UTILIZATION OF MEDITERRANEAN SOIL AS A NURSERIES MEDIA FOR BULULAWANG SUGARCANE (Saccharum officinarum L.) VARIETY WITH THE ADDITIONAL OF ORGANIC FERTILIZER AT DIFFERENT DOSES}

\author{
Saktiyono Sigit Tri Pamungkas ${ }^{*}$ \\ ${ }^{1}$ Program Studi Budidaya Tanaman Perkebunan \\ 1*Email: saktibaguspamungkas@gmail.com
}

\begin{abstract}
The decrease in the productivity of sugarcane (Saccharum officinarum L.) can be pursued through intensification with treatment in the nursery. However, it is increasingly difficult to find a good growing medium for plants, such as mediterranean soil must be managed. One of the efforts is to increase soil fertility by adding livestock manure which has the potential as organic fertilizer so that it is expected to improve soil structure and add nutrients. This study aims to determine the dose of organic fertilizer in sugarcane bud set nurseries on media with the addition of lime soil. This research was carried out at the independent farm. This study used a non-factorial Randomized Block Design (RAK) with one factor, namely the dose of organic fertilizer $(0,125,250,375$, and 500 grams/polybag) with 3 replications. The results showed that the addition of organic fertilizer had a significant effect on plant height, number of leaves, and stem diameter of sugarcane nurseries. The best application of organic fertilizer in sugarcane bud set nurseries is a dose of 250 grams/polybag.
\end{abstract}

Keywords: Sugarcane, Nurseries, Mediterranean Soil, Livestock Manure, Organic Fertilizer

\begin{abstract}
ABSTRAK
Penurunan produktivitas tebu (Saccharum officinarum L.) dapat diupayakan melalui intensifikasi melalui pembibitan. Namun media tumbuh yang baik untuk tanaman semakin sulit ditemukan sehingga lahan yang memiliki kendala seperti jenis tanah kapuran (mediterania) harus dilakukan pengelolaan. Salah satu upaya yaitu meningkatkan kesuburan tanah dengan penambahan kotoran ternak yang berpotensi sebagai pupuk kandang sehingga diharapkan dapat memperbaiki struktur tanah dan menambah unsur hara. Penelitian ini bertujuan untuk mengetahui dosis pupuk pupuk kandang pada pembibitan bud set tebu pada media dengan penambahan tanah kapuran. Penelitian ini dilaksanakan di Kebun Mandiri pada bulan Februari sampai bulan Mei 2020. Penelitian ini menggunakan Rancangan Acak Kelompok (RAK) non faktorial dengan 1 faktor yaitu dosis
\end{abstract}


pupuk kandang $(0,125,250,375$, dan 500 gram/polibag) dengan 3 ulangan. Hasil penelitian menunjukkan penambahan pupuk kandang berpengaruh nyata terhadap tinggi tanaman, jumlah daun, dan diameter batang bibit tebu. Pemberian pupuk kandang yang terbaik pada pembibitan bud set tebu yaitu dosis 250 gram/polibag.

Kata Kunci: Tebu, Pembibitan, Tanah Kapuran, Pupuk Kandang, Pupuk Organik

\section{PENDAHULUAN}

Salah satu masalah yang dihadapi oleh Indonesia berkaitan dengan masalah gula yaitu produksi gula yang cenderung mengalami penurunan sehingga belum dapat mencukupi kebutuhan gula konsumsi. Penurunan produksi gula disebabkan oleh menurunnya produktivitas dan efisiensi industri gula secara keseluruhan. Secara agronomis menurunnya produktivitas disebabkan oleh kebutuhan akan hara tanaman tebu tidak tercukupi secara optimal yang membuat produktifitas tebu belum optimal.

Upaya dalam usaha produktivitas tebu adalah melaksanakan intensifikasi. Upaya intensifikasi dapat dilakukan melalui pembibitan tanaman tebu dan melakukan pengelolaan tanah marjinal seperti tanah kapuran (mediterania). Tanah ini karena proses kondisi geografis dan agroklimat sehingga terdorong menjadi tanah marjinal. Tanah ini memiliki permasalahan antara lain terlalu basa, solum dangkal, bahan organik rendah, kadar hara makro (N, P, K) dan mikro (Fe dan $\mathrm{Zn}$ ), daya simpan air rendah dan drainase yang tidak baik. Tanah ini memiliki $\mathrm{pH}$ yang tinggi (basa) dan memiliki rata-rata kandungan $\mathrm{C}$-organik yang rendah yaitu sekitar $1,58 \%$. Dengan alasan tersebut, maka pada tanah jenis ini dapat diolah dengan cara melakukan penambahan pupuk menggunakan pupuk organik yang berpotensi menambah kandungan bahan organik sehingga unsur hara yang terdapat dalam media agar tersedia bagi bibit tanaman tebu.

Pembibitan tebu adalah faktor penentu produksi gula apabila kualitas bibit tebu baik maka akan menentukan keberhasilan budidaya tebu dan menghasilkan rendemen tinggi sehingga produksi gula tinggi. Kualitas bibit yang baik ditandai dengan pertumbuhan bibit yang optimal. Pembibitan merupakan kegiatan budidaya tanaman tebu yang sangat penting diperhatikan, hal ini dikarenakan akan mempengaruhi produktivitas tanaman tebu selama masa penanaman. Secara umum bibit tebu dapat tumbuh pada berbagai macam media tanah. Bibit tebu akan tumbuh baik pada tanah bertekstur lempung-berliat, lempung-berpasir dan lempung-berdebu, dengan kedalaman solum yang cukup dalam $(0,5-1,0 \mathrm{~m})$ dan drainase baik. Drainase yang jelek dapat mengakibatkan pertumbuhan yang terhambat karena terjadinya kerusakan-kerusakan pada akar (Wijayanti, 2008). Bibit tebu akan tumbuh dengan optimal pada media dengan $\mathrm{pH} 6-7$. Pada $\mathrm{pH}$ yang tinggi menyebabkan ketersediaan hara menjadi tidak optimal (Indrawanto, 2010). Unsur komponen tanah yang diamati yaitu sifat biologi dan kimia. Komponen biologi merupakan komponen mikroorganisme komplek yang berada di tanah sedangkan komponen kimia merupakan komponen unsur-unsur yang terkandung dalam tanah. Komponen kimia berperan penting dalam menentukan sifat dan ciri tanah. Kondisi tersebut tidak dimiliki pada tanah kapuran. 
Tanah kapuran adalah jenis tanah yang masih mengandung mineral primer yang mudah lapuk, cenderung basa, kapasitas tukar kation (KTK) dan hara yang kurang tersedia bagi tanaman. Jenis tanah ini muncul karena adanya kadar besi yang tinggi disertai kadar humus yang rendah akibat mengalami pelapukan intensif dan perkembangan tanah lanjut, sehingga terjadi pelindian unsur hara, bahan organik dan silika dengan meninggalkan sesquioksida sebagai sisa berwarna merah, sehingga memiliki waran dari coklat abu-abu sampai coklat kemerahan hingga cenderung putih kekuningan (Tan, 2000 dalam Wijarnako, 2007). Penurunan bahan organik pada lapisan atas terjadi karena adanya pengelolaan lahan yang intensif, untuk itu diperlukan suatu cara pengelolaan tertentu di samping dengan penambahan bahan organik (Munir, 1996 dalam Sarsini, 2008). Namun demikian tanah marjinal ini dapat digunakan sebagai material media tanam untuk pembibitan tebu.

Limbah ternak kambing (manure livestock) dapat dimanfaatkan sebagai pupuk organik penambah hara pada media pembibitan. Limbah tersebut apabila sudah terfermentasi akan menjadi pupuk organik yang baik dan berguna bagi penambah hara pada tanaman (Subekti, 2005). Sebagai pupuk organik, pupuk kandang memiliki hara yang sedikit, kelebihannya adalah selain menambah unsur hara, juga sebagai pembenah tanah sehingga dapat mempertinggi humus, memperbaiki struktur tanah. Pupuk kandang lebih lambat bereaksi, karena didalam tanah, pupuk kandang lebih untuk memperbaiki tanah sehingga persediaan unsur hara berangsur-angsur menjadi bebas/tersedia bagi tanaman (Subekti, 2005).

Penambahan bahan organik (pupuk kandang) ke dalam tanah dapat memperbaiki agregasi tanah sehingga mampu meningkatkan jumlah pori-pori tanah dan pada akhirnya menjadi media yang cocok bagi media pembibitan, sehingga berdampak pada meluasnya jangkauan akar dan meningkatnya serapan hara tersedia sehingga bibit tanaman dapat tumbuh dengan baik. Analisis kandungan unsur hara pupuk kandang pada salah satu perusahaan kelapa sawit pada tahun 2016 menunjukan bahwa pupuk kandang kotoran kambing mengandung N-total 1,38\%, P-total 0,65\%, K-total 2,78\%, dan C-organik 20,18\% (Amir, 2017). Pada tanah marjinal, pupuk kandang dianjurkan diberikan pada saat pengolahan tanah dengan dosis 2-5 ton/ha. Pupuk ini berguna untuk memperbaiki struktur tanah agar mikroorganisme tanah dapat berkembang secara optimal (Wirawan, 2002 dalam Sarsini, 2008). Pada areal penanaman tebu dosis penggunaan pupuk kandang yaitu 10-20 ton/ha (Amir, 2017), sedangkan Firokhman (2016) menyatakan bahwa, pemberian pupuk kandang kambing dosis 42 ton/ha pada tebu setelah kepras 2 memberikan pengaruh nyata terhadap bobot kering tebu pada saat 6 bulan setelah dilakukan keprasan. Menurut Safitri, et al., (2017) bahwa dosis pupuk kandang kambing yang diberikan hingga mencapai 40 ton/ha, maka semakin meningkatkan seluruh variabel pengamatan tinggi tanaman, diameter tongkol, panjang tongkol, bobot tongkol per tanaman, dan bobot 100 butir pada tanaman Jagung (Zea mays L.).

Atas dasar tersebut, maka pemanfaatan tanah kapuran sebagai media pembibitan tebu (bud set) dengan penambahan pupuk organik perlu dilakukan. Adapun tujuan dari penelitian ini adalah untuk mengetahui dosis pupuk organik 
(pupuk kandang kotoran kambing) yang optimum untuk pertumbuhan pada pembibitan bud set tebu dimedia tanah kapuran.

\section{METODE PENELITIAN}

Penelitian ini dilaksanakan bulan Februari 2020 sampai Mei 2020 di Kebun Praktek Terpadu Politeknik LPP. Alat yang digunakan dalam penelitian yaitu cangkul, meteran, gembor, timbangan, alat tulis, penggaris, kertas label, kamera, jangka sorong, ember, derigen, plastik, pengaduk, gelas ukur, sedangkan bahan yang digunakan adalah bibit bud set tebu varietas Bululawang (BL), polybag, air, EM4, kotoran kandang kambing, debu sabut, jonggol jagung, bekatul dan tanah kapuran diambil dari Sedayu, Bantul. Metode yang digunakan adalah Rancangan Acak Kelompok (RAK) non faktorial dengan 5 perlakuan dan 3 ulangan sebagai blok. Factor yang digunakan adalah pupuk organik kotoran kambing (pupuk kandang) yang terdiri dari perlakuan PK0 (tanpa pemberian pupuk kotoran kambing), PK1 (pupuk kotoran kambing 125 gram/polybag), PK2 (pupuk kotoran kambing 250 gram/polybag), PK3 (pupuk kotoran kambing 375 gram/polybag) dan PK4 (pupuk kotoran kambing 500 gram/polybag). Kotoran kambing merupakan bahan organik yang apabila dilakukan pengelolaan lebih lanjut dapat digunakan sebagai penambah unsur hara dalam bentuk pupuk kandang (Alex, 2011). Pembuatan (fermentasi) pupuk kandang menurut Trivana et al., (2017) yaitu kotoran kambing yang sudah matang (kering) dihancurkan, kemudian dicampur dengan debu sabut, jonggol jagung dan bekatul dengan perbandingan 1:1. Campuran bahan bahan organik tersebut disiram dengan larutan EM4 (100 ml EM4/10 liter air) secara merata sambal diaduk. Tutup rapat tumpukan bahan-bahan organik dengan plastik terpal. Proses pembalikan dilakukan setiap 5 hari sekali sampai proses pengomposan selesai. Pupuk kompos yang telah matang dicirikan dengan warna yang hitam kecoklatan, teksturnya gembur, tidak berbau. Pupuk kandang di ayak dan dicampurkan dengan tanah sesuai perlakuan dan dimasukan kedalam polybag, di siram dan dibiarkan selama 1 minggu untuk kemudian ditanam bud set tebu. Variabel pengamatan yang dilakukan pada penelitian ini adalah tinggi tanaman $(\mathrm{cm})$, jumlah daun (helai) dan diameter batang $(\mathrm{mm})$. Data diambil setiap 1 minggu sekali kemudian diuji menggunakan ANOVA dan DMRT taraf 5\% apabila menunjukan pengaruh nyata.

\section{HASIL DAN PEMBAHASAN}

\section{Tinggi Tanaman}

Hasil Uji lanjut pada Tabel 1, menunjukan bahwa pemberian pupuk kandang menunjukkan nilai rata-rata tertinggi yaitu $161,5 \mathrm{~cm}$ pada perlakuan PK1 (125 gram/polibag) yang tidak berpengaruh nyata dengan perlakuan dosis pupuk kandang 250 gram/polibag (PK2), 375 gram/polibag (PK3) dengan rata-rata tinggi tanaman berturut-turut $158,67 \mathrm{~cm}, 159,13 \mathrm{~cm}$, dan $149,14 \mathrm{~cm}$, namun berpengaruh nyata pada perlakuan PK0 (kontrol) dan PK4 (500 gram/polibag) dengan rata-rata tinggi tanaman berturut-turut $148,27 \mathrm{~cm}$ dan $149,12 \mathrm{~cm}$. 
Tabel 1. Pengaruh Dosis Pupuk Kandang Terhadap Tinggi Bibit Tebu

\begin{tabular}{cccccc}
\hline & PK0 & PK1 & PK2 & PK3 & PK4 \\
\hline 141,67 & 151,5 & 145,67 & 147,83 & 128,03 \\
& 145,67 & 167,33 & 166,17 & 161,67 & 162,67 \\
& 157,67 & 167,67 & 162,33 & 170,33 & 147,17 \\
& 151,67 & 164 & 162,33 & 157,17 & 154,67 \\
& 144,67 & 157 & 156,83 & 158,63 & 153,17 \\
\hline Rerata & $148,27 \mathrm{a}$ & $161,5 \mathrm{~b}$ & $158,67 \mathrm{~b}$ & $159,13 \mathrm{~b}$ & $149,14 \mathrm{a}$
\end{tabular}

Keterangan : Angka yang diikuti huruf yang tidak sama menunjukkan berpengaruh nyata DMRT

Hasil Penelitian menunjukan bahwa pemberian pupuk kandang dosis 125 gram/polibag (PK1) menghasilkan tinggi tanaman tertinggi yaitu $161,5 \mathrm{~cm}$ dan telah memenuhi standar pertumbuhan tinggi tanaman bibit tebu, ini cukup selaras dengan hasil penelitian lain yang menunjukan bahwa, aplikasi pupuk kadang pada dosis 20 hingga 30 ton/ha menghasilkan tinggi tanaman yang nyata pada tanaman jagung manis. Pupuk kandang 42 ton/ha sebagai perlakuan yang menunjukkan tinggi tanaman tertinggi pada tanaman tebu (Firokhman, 2016). Perlakuan dosis pupuk kandang kambing 30 ton/ha memberikan pengaruh nyata terhadap tinggi tanaman jagung manis (Aditya, 2019). Pemberian dosis pupuk kandang 30 ton/ha menghasilkan tinggi tanaman padi tertinggi (Junaidi, 2017). Menurut Dwi (2016) dalam penelitiannya menyatakan bahawa, aplikasi pupuk kandang kambing 40 ton/ha menghasilkan rerata tinggi tanaman tertinggi pada tanaman dengan famili Cucurbitaceae yaitu 160,13 cm.

Penambahan pupuk kandang kambing mampu menambah ketersediaan hara (N, P dan $\mathrm{K}$ ) dalam keadaan yang seimbang dan tersedia untuk tanaman tebu. Pertumbuhan tinggi tanaman disebabkan adanya pembelahan dan perpanjangan sel yang dipengaruhi oleh suplai unsur hara terutama unsur N. Selaras dengan pendapat dari Sidemen et al. (2017) yang menyatakan bahwa tanaman tidak cukup hanya mengandalkan unsur hara yang ada di dalam tanah saja melainkan perlu di tambahkan bahan organik lain dari luar seperti kotoran ternak. Penambahan nitrogen yang cukup pada tanaman akan mempercepat laju pembelahan dan perpanjangan akar, batang, dan daun. unsur hara $\mathrm{N}$ yang dibutuhkan tanaman dalam merangsang proses pada pertumbuhan vegetatif tanaman tebu secara keseluruhan untuk pertumbuhan tinggi tanaman. Selaras dengan pendapat Yuanita (2016) yang menyatakan bahwa penambahan pupuk organik kotoran kambing dapat mempengaruhi pemanjangan sel dan tinggi tanaman. Lakitan (2011) menyatakan bahwa unsur hara $\mathrm{N}$ merupakan penyusun senyawa asam amino yang diperlukan dalam pembentukan dan pertumbuhan bagian vegetatif tanaman yaitu akar, sehingga akan berpengaruh terhadap organ vegetatif lainnya. Nitrogen $(N)$ merupakan hara makro utama yang sangat penting untuk pertumbuhan tanaman yang berfungsi sebagai komponen dari asam nukleat, protein, hormon, klorofil dan koenzym (Lestari, 2015).

Unsur P berperan dalam pembentukan ATP sebagai energi yang dibutuhkan tanaman dalam setiap aktivitas pembesaran sel dan perpanjangan sel diantaranya 
batang yang dapat meningkatkan pertumbuhan tinggi tanaman (Amin, 2017). Unsur K berfungsi sebagai agen katalis yang berperan dalam proses metabolisme tanaman yaitu meningkatkan aktivasi enzim, mengurangi kehilangan air transpirasi melalui pengaturan stomata, meningkatkan produksi adenosine triphosphate (ATP), membantu translokasi asimilat, dan meningkatkan serapan $\mathrm{N}$ dan sintesis protein (Rukmi, 2010). Fosfor (P) merupakan salah satu unsur hara esensial yang diperlukan dalam jumlah relatif banyak oleh tanaman tebu (Briliyani, 2017). Unsur P berfungsi untuk memacu petumbuhan akar. Pada reaksi enzimatis, unsur $\mathrm{P}$ berfungsi sebagai pendukung reaksi-reaksi enzim fosforilase. Unsur ini merupakan bagian dari inti sel yang sangat penting untuk pembelahan sel dan juga untuk perkembangan jaringan meristematik sehingga akan mempengaruhi tinggi tanaman secara umum (Hidayat, 2008).

Menurut Lakitan (2011) unsur $\mathrm{K}$ berperan sebagai aktivator dari berbagai enzim yang essensial dalam reaksi-reaksi fotosintesis dan respirasi serta enzim yang berperan dalam sintesis pati dan protein. Ketersediaan $\mathrm{K}$ yang cukup maka diduga mempengaruhi proses metabolisme karbohidrat dan protein, sintesis protein, serta mengaktifkan berbagai enzim dalam proses fisiologis tanaman (Dewi, 2015). Unsur Kalium (K) merupakan salah satu unsur hara makro yang dibutuhkan dalam jumlah yang yang besar, yang berfungsi dapat menambah ketahanan tanaman terhadap penyakit tertentu dan meningkatkan sistem perakaran, cenderung menghalangi efek rebah (lodging) tanaman dan melawan efek buruk yang disebabkan oleh terlalu banyaknya unsur N (Rukmi, 2010). Unsur $\mathrm{K}$ juga merupakan agen katalis dalam proses metabolisme tanaman yaitu meningkatkan aktivasi enzim, mengurangi kehilangan air transpirasi melalui pengaturan stomata, meningkatkan produksi adenosine triphosphate (ATP), membantu translokasi asimilat (Nursyamsi, 2006).

\section{Jumlah Daun}

Tabel 2. Pengaruh Dosis Pupuk Kandang Terhadap Jumlah Daun Tebu

\begin{tabular}{cccccc}
\hline & PK0 & PK1 & PK2 & PK3 & PK4 \\
\hline 10,33 & 11 & 10,67 & 10,67 & 10,33 \\
& 9 & 11 & 11,6 & 11 & 11 \\
& 10,33 & 11,33 & 11 & 11,67 & 9,67 \\
& 10 & 11,33 & 11,33 & 10,67 & 11,33 \\
Rerata & 10 & 11,33 & 11,67 & 12 & 11 \\
\hline Keran & $9,93 \mathrm{a}$ & $11,2 \mathrm{~b}$ & $11,27 \mathrm{~b}$ & $11,2 \mathrm{~b}$ & $10,67 \mathrm{~b}$ \\
\hline
\end{tabular}

Keterangan : Angka yang diikuti huruf yang tidak sama menunjukkan berpengaruh nyata DMRT

Hasil Uji lanjut pada Tabel 2, menunjukan bahwa pemberian pupuk kandang menunjukkan nilai rata-rata tertinggi yaitu 11,27 helai dengan perlakuan dosis 250 gram/polibag (PK2) dan tidak berpengaruh nyata dengan perlakuan dosis pupuk kandang 125 gram/polibag (PK1), 375 gram/polibag (PK3), dan 500 gram/polibag (PK4) dengan rata-rata jumlah daun berturut-turut, 11,2 helai, 11,2 helai, dan 10,67 helai, namun berpengaruh nyata dengan perlakuan PK1 (kontrol) 
sebanyak 9,93 helai. Hasil tersebut selaras dengan penelitian lain yang menunjukan bahwa, aplikasi pupuk kandang kambing 42 ton/ha mampu meningkatkan jumlah daun pada tanaman tebu (Firokhman, 2016). Perlakuan dosis pupuk kandang kambing 30 ton/ha mampu memberikan pengaruh nyata terhadap jumlah daun tanaman jagung manis (Aditya, 2019). Jumlah helai daun terbanyak pada tanaman padi dihasilkan oleh perlakuan dosis pupuk kandang 30 ton/ha yaitu 19,78 helai (Junaidi, 2017). Aplikasi pupuk kandang kambing 40 ton/ha menghasilkan rerata tertinggi pada jumlah daun tanaman famili Cucurbitaceae yaitu 13,4 helai (Dwi, 2016).

Penambahan pupuk kandang cukup efektif sebagai bahan penambah unsur hara (N,P dan K), sehingga dapat berpengaruh terhadap jumlah daun bibit tebu. Jumlah daun sangat penting karena semakin banyak jumlah daun maka kapasitas fotosintesis akan lebih besar sehingga semakin banyak fotosintat yang dihasilkan untuk memenuhi kebutuhan pertumbuhan tanaman. Daun mengandung pigmen klorofil yang berfungsi menangkap cahaya matahari yang digunakan dalam proses fotosintesis. Semakin banyak jumlah daun tanaman maka fotosintat yang dihasilkan semakin meningkat (Lestari, 2015).

Unsur $\mathrm{N}$ merupakan hara makro yang dapat merangsang pertumbuhan tanaman secara keseluruhan, merupakan bagian dari sel (organ) tanaman, berfungsi untuk sintesa asam amino dan protein dalam tanaman dan merangsang pertumbuhan vegetatif (warna hijau) seperti daun. Unsur $\mathrm{N}$ berperan dalam pembentukan klorofil yang berfungsi sebagai pengabsorpsi cahaya matahari sehingga dapat meingkatkan laju fotosintesis (Amin, 2017). Pemberian pupuk kandang mampu menambah hara $\mathrm{N}$ dalam tanah dan tersedia untuk tanaman sehingga dapat diserap tanaman dengan baik untuk pertumbuhan tanaman. Unsur $\mathrm{N}$ dimanfaatkan tanaman untuk pembentuk klorofil, asam amino dan protein sehingga mampu membentuk organ-organ pertumbuhan salah satunya pembentukan daun. Menurut Lakitan (2011) unsur hara yang paling berpengaruh terhadap pertumbuhan dan perkembangan daun adalah unsur $\mathrm{N}$, jumlah daun yang lebih banyak umumnya di sebabkan oleh kandungan unsur $\mathrm{N}$ yang banyak. Myrna (2006) menyatakan bahwa tersedianya unsur nitrogen pada awal pertumbuhan akan mempengaruhi jumlah dan luas daun yang terbentuk, dengan demikian kandungan klorofil yang dihasilkan juga lebih tinggi untuk tanaman mampu menghasilkan karbohidrat/asimilat dalam jumlah yang cukup untuk pertumbuhan vegetatif. Selaras dengan pendapat Mimbar (1999 dalam Indriyani et al. 2018) yang menyatakan bahwa unsur $\mathrm{N}$ membantu inisiasi daun yang mengakibatkan jaringan meristematik pada titik tumbuh batang semakin aktif akibatnya menambah tinggi tanaman dan menambah jumlah daun.

Unsur $\mathrm{P}$ juga berfungsi dalam proses pengangkutan energi hasil metabolisme dalam tanaman, merangsang pertumbuhan akar, merangsang pembelahan sel dan pembesaran jaringan sel. Unsur Kalium (K) berperan dalam proses fotosintesis, pengangkutan hasil asimilasi, enzim dan mineral termasuk air. Unsur P merupakan unsur hara esensial kedua setelah $\mathrm{N}$ yang berperan penting dalam proses fotosintesis dan perkembangan akar (Herman, 2013). Unsur P dalam bentuk tersedia didalam tanah akan dimanfaatkan tanaman untuk pertumbuhan akar sehingga penyerapan hara oleh akar optimal akan mempengaruhi laju 
fotosintesis pada tanaman, semakin tersedia unsur hara tersebut maka menghasilkan fotosintat yang optimal dan digunakan untuk pembentukan dan perkembangan daun. Menurut Malherbe (1964 dalam Zubaidah 2007) salah satu fungsi $\mathrm{P}$ terpenting dalam tanaman adalah sebagai bahan pembangunan nukleoprotein yang terdapat dalam setiap inti sel, pembentukan sel-sel baru tanaman termasuk penyusun organ tanaman (daun). Menurut Soepardi (1983 dalam Rosman, 2004) fosfor berperan dalam pembelahan sel dan pembentukan lemak albumin, merangsang perkembangan akar halus dan kasar. Ketersediaan $\mathrm{P}$ tanah dalam tanah secara tidak langsung akan meningkatkan serapan unsur hara lainnya seperti $\mathrm{N}$ dan $\mathrm{K}$ serta peranannya dalam memacu produksi hormon pertumbuhan tanaman (Herman, 2013). Hal ini sesuai dengan hasil penelitian Sarief (1986 dalam Hidayat 2008) bahwa unsur P berperan dalam pembelahan sel, penyusunan lemak dan protein, juga untuk perkembangan jaringan meristem yang dapat merangsang pertumbuhan akar sehingga pembentukan daun meningkat.

Unsur $\mathrm{K}$ merupakan unsur hara bersifat mobile yang berfungsi sebagai aktivator enzim dan berperan dalam sintesis protein dan pati, translokasi asimilat di dalam jaringan pengangkut, mengatur pergerakan stomata dan tekanan osmotik potensial sel, serta mengendalikan tekanan osmotik di dalan tanaman secara keseluruhan sehingga tanaman menjadi lebih tahan terhadap cekaman air. Penambahan unsur $\mathrm{K}$ selain unsur $\mathrm{N}$ dan $\mathrm{P}$ secara berimbang dibutuhkan dalam proses fotosintesis, fiksasi $\mathrm{CO} 2$ dan transfer fotosintat ke berbagai penjuru tanaman, sehingga dengan meningkatnya laju fotosintesis maka fotosintat yang dihasilkan juga meningkat sehingga pertumbuhan tanaman menjadi lebih baik serta menghasilkan jumlah daun pada tanaman. Menurut Lakitan (2011) unsur K berperan sebagai aktivator dari berbagai enzim dan berperan dalam sintesis pati dan protein hasil fotosintat di daun. Menurut Setiono (2020), unsur K dapat berperan dalam proses perkuatan dinding sel tanaman dan memperluas kanopi daun untuk mendukung laju fotosintesis.

\section{Diameter Batang}

Tabel 3. Pengaruh Dosis Pupuk Kandang Terhadap Diameter Batang Tebu

\begin{tabular}{cccccc}
\hline & PK0 & PK1 & PK2 & PK3 & PK4 \\
\hline 10,1 & 12,33 & 11,9 & 11,03 & 11,43 \\
& 8,4 & 13,33 & 13,13 & 11,9 & 12,47 \\
& 11,8 & 12,8 & 13,3 & 13,8 & 11,97 \\
& 10,53 & 12,73 & 13,23 & 10,5 & 13,63 \\
& 10,67 & 13,2 & 13,43 & 13,9 & 11,57 \\
\hline Rerata & $10,3 \mathrm{a}$ & $12,88 \mathrm{ab}$ & $13 \mathrm{~b}$ & $12,23 \mathrm{ab}$ & $12,21 \mathrm{~b}$ \\
\hline
\end{tabular}

Keterangan : Angka yang diikuti huruf yang tidak sama menunjukkan berpengaruh nyata DMRT

Hasil Uji lanjut pada Tabel 3, menunjukan bahwa pemberian pupuk kandang kambing menunjukkan nilai rata-rata tertinggi yaitu $13 \mathrm{~mm}$ dengan perlakuan dosis 250 gram/polibag (PK2) dan tidak berpengaruh nyata pada perlakuan dosis pupuk kandang 125 gram/polibag (PK1), 375 gram/polibag 
(PK3), dan 500 gram/polibag (PK4) dengan rata-rata diameter batang berturutturut $12,88 \mathrm{~mm}, 12,23 \mathrm{~mm}$, dan $12,21 \mathrm{~mm}$, namun berpengaruh nyata pada perlakuan kontrol (PK0) sebesar 10,3 mm. Hasil penelitian pada tanaman lain menunjukan bahwa, penambahan pupuk kandang kambing 30 ton/ha menghasilkan diameter batang tertinggi pada tanaman jagung manis (Aditya, 2019), pemberian pupuk kandang kambing 10 ton/ha menghasilkan diameter batang tertinggi pada tanaman jagung manis pada umur 42 HST (Tadjudin, 2016) dan pemberian pupuk kandang kambing pada dosis 30 ton/ha menghasilkan rerata diameter batang tertinggi pada tanaman terung gelatik yaitu 8,76 mm (Achmad, 2019). Berdasarkan hal tersebut, maka penambahan pupuk kandang dapat menambah ketersediaan unsur hara baik N, P dan $\mathrm{K}$.

Unsur $\mathrm{N}$ yang tersedia bagi bibit tebu selama fase pertumbuhan dapat merangsang aktivitas metabolisme yaitu proses fotosintesis akan meningkat sehingga fotosintat yang dihasilkan juga meningkat dapat dialokasikan untuk pertumbuhan diameter batang sehingga menyebabkan laju pembelahan, pemanjangan sel serta pembentukan jaringan berjalan cepat. Unsur $\mathrm{N}$ penting dalam hal pembentukan hijau daun yang berguna sekali dalam proses fotosintesis. Klorofil yang tersedia dalam jumlah yang cukup pada daun tanaman akan meningkatkan kemampuan daun untuk menyerap cahaya matahari, sehingga proses fotosintesis akan berjalan lancar. Fotosintat yang dihasilkan akan dirombak kembali melalui proses respirasi dan menghasilkan energi yang diperlukan oleh sel untuk melakukan aktifitas seperti pembelahan dan pembesaran sel batang (Cahyani, 2016).

Penambahan pupuk kandang dalam penelitian ini menyebabkan kesediaan $\mathrm{P}$ dalam tanah bertambah sehingga dapat memacu serapan $\mathrm{P}$ oleh akar tanaman tebu sehingga dapar merangsang pertumbuhan diameter batang, sesuai dengan pendapat (Sarief, 1986 dalam Hidayat, 2008) yang menyatakan bahwa unsur hara yang cukup tersedia saat pertumbuhan tanaman mengakibatkan fotosintesis berjalan lebih aktif, dengan demikian proses pemanjangan, pembelahan dan diferensiasi sel (diameter batang) akan terjadi lebih baik yang dapat mendukung pertumbuhan tanaman. Unsur P berperan dalam pembentukan adenosin trifosfat (ATP). ATP adalah energi yang dibutuhkan tanaman dalam setiap aktivitas sel yang melipiti pembesaran sel dan perpanjangan sel (Amin, 2017). Selain itu, unsur $\mathrm{P}$ juga berfungsi merangsang pembelahan sel tanaman dan memperbesar jaringan sel yang aktif membelah (parenkim) untuk mendukung pertumbuhan batang tanaman (Cahyani, 2016). Selaras dengan pendapat Setiono (2020) yang menyatakan bahwa selain sebagai hara esensial unsur $\mathrm{P}$ juga membantu memacu proses pembentukan karbohidrat yang akan mendorong pembesaran sel yang berakibat pada meningkatnya diameter batang.

Unsur hara $\mathrm{K}$ berfungsi sebagai agen katalis yang berperan dalam proses metabolisme tanaman yaitu meningkatkan aktivasi enzim, mengurangi kehilangan air transpirasi melalui pengaturan stomata (Soegiman, 1982 dalam Rukmi, 2010). Penambahan pupuk kandang pada penelitian ini cukup efektif mengurangi kehilangan air akibat proses transpirasi melalui stomata sehingga proses fotosintesis berjalan optimal dan menghasilkan fotosintat sebagai energi yang digunakan untuk pembelahan dan pembesaran sel yang terdapat pada batang 
tanaman (diameter batang). Pada saat kekurangan air, sebagian stomata daun menutup sehingga terjadi hambatan masuknya $\mathrm{CO} 2$ dan menurunkan aktivitas fotosintesis. Selain menghambat aktivitas fotosintesis, kekurangan air juga menghambat sintesis protein dan dinding sel (Salisbury, 1992 dalam Cahyani, 2016). Tanaman yang mengalami kekurangan air secara umum mempunyai ukuran yang lebih kecil dibandingkan dengan tanaman yang tumbuh normal (Kurniasari et al., 2010). Unsur K berperan dalam pembentukan karbohidrat dan translokasi pati ke batang tanaman tebu dan memperlancar proses translokasi hara dari akar ke batang, selaras dengan pendapat Rotama (2015), bahwa K berperan dalam meningkatkan diameter batang, khususnya dalam peranannya sebagai jaringan yang menghubungkan antara akar dan daun pada proses transportasi unsur hara dari akar ke daun (Leiwkabessy, 1988 dalam Rotama 2015). Tanaman yang mendapatkan K cukup akan tumbuh lebih cepat karena $\mathrm{K}$ dapat memelihara tekana turgor sel secara konstan. Tekanan turgor sel yang konstan dapat memacu pembesaran sel-sel yang menyusun jaringan maristem, sehingga dapat menghasilkan tanaman yang tahan rebah karena batang yang berkembang dan tumbuh dengan baik (Laegraid et a.l, 1999 dalam Haris, 2009).

\section{KESIMPULAN DAN SARAN}

Tanah marjinal jenis kapuran (mediterania) dapat dimanfaatkan sebagai media alternatif pembibitan tebu varietas bululawang. Limbah kotoran kambing dapat dimanfaatkan agar memiliki nilai tambah dengan sedikit perlakuan (fermentasi) sebagai pupuk organik penambah hara dan memperbaiki struktur tanah. Hasil penelitian menunjukan bahwa pemberian pupuk kandang kotoran kambing berpengaruh nyata terhadap pertumbuhan bibit tebu bud set varietas bululawang dengan perlakuan terbaik dosis 250 gram/polybag (PK2). Saran untuk penelitian selanjutnya adalah pemanfaatan kotoran kambing untuk pupuk organik dengan penambahan mikroorganisme aktif seperti Trhicoderma sp. atau dengan modifikasi bahan tambahan yang bermanfaat sebagai bahan pembenah tanah pada berbagai jenis tanah marjinal.

\section{DAFTAR PUSTAKA}

Aditya, B. 2019. Pengujian Berbagai Dosis Pupuk Kandang Kambing Untuk Pertumbuhan dan Produksi Jagung Manis Organik (Zea mays var. Saccharata Sturt). Jurnal Buletin Agrihorti. Volume: 1 No: 2.

Alex, S. 2011. Sukses Mengolah Sampah Organik Menjadi Pupuk Organik. Pustaka Baru Press, Yogyakarta.

Amin., A. A, Arnis En Yulia, dan Nurbaiti. 2017. Pemanfaatan Limbah Cair Tahu Untuk Pertumbuhan dan Produksi Tanaman Pakcoy (Brassica Rapa L.). JOM Faperta. Volume: 4 No: 2. 
Amir., N, Heniyati Hawalid, Ismail Arifal Nurhuda 2017. Pengaruh Pupuk Kandang Terhadap Pertumbuhan Beberapa Varietas Bibit Tanaman Tebu (saccharum officinarum 1.) di Polybag. Klorofil. Volume: 2 No: 2.

Briliyani, Y . M, Wiwin S. dan Kurniawan P. 2017. Pengaruh Berbagai Media Tanam Terhadap Pembibitan Bud Chip Tanaman Tebu (Saccharum Officinarum L.) Varietas Bl. Jurnal Produksi Tanaman. Volume: 5 No: 2.

Cahyani, S., Albertus S, Abdul A. 2016. Respons Pertumbuhan Vegetatif Tanaman Tebu (Saccharum Officinarum L.) Ratoon I Terhadap Pemberian Kombinasi Pupuk Organik dan Pupuk Anorganik. Jurnal Aip. Volume: 4 No: 2.

Dwi, P, Hamidah. H, Abdul. R. 2016. Aplikasi Limbah Panen Padi Dan Pupuk Kalium Untuk Meningkatkan Hara Kalium dan Pertumbuhan Serta Produksi Kedelai (Glycine Max (L.) Merrill.). Jurnal Online Agroteknologi. Volume: 3 No: 2.

Firokhman., A, Agus Suryanto, dan Setyono Yudo Tyasmoro. 2016. Kajian Umur Kepras dan Dosis Pupuk Kandang Kambing Terhadap Pertumbuhan Vegetatif Tanaman Tebu (Saccharum officinarum L.). Jurnal Produksi Tanaman. Volume: 4 No: 6.

Haris., A. S dan Veronica. K. 2009. Studi Pemupukan Kalium Terhadap Pertumbuhan dan Hasil Jagung Manis (Zea mays saccharata Sturt) Varietas Super Bee. Sains dan Teknologi. Volume: 2 No: 1.

Herman, M Dan Dibyo, P. 2013. Pengaruh Mikroba Pelarut Fosfat Terhadap Pertumbuhan dan Serapan Hara P Benih Kakao (Theobroma Cacao L.). Jurnal Buletin Ristri. Volume: 4 No: 2.

Hidayat, H. 2008. Perumbuhan dan Produksi Kacang Tanah (Arachis Hypogea. L) Varietas Lokal Madura Pada Berbagai Jarak Tanam dan Dosis Pupuk Fosfor. Jurnal Agrovigor. Volume: 1 No: 1.

Indrawanto., Chandra, Purwono, Siswanto ,M. Syakir dan Widi Rumini, MS. 2010. Budidaya dan Pasca Panen Tebu. Penerbit ESKA Media, Jakarta.

Indriyani, Nofita, Tatik Wardiyati dan Moch. Nawawi. 2018. Pengaruh Macam Pupuk Kandang Terhadap pertumbuhan dan Hasil Tanaman Brassica rapa L dan Brassica juncea L. Jurnal produksi Tanaman. Volume: 5 No: 6.

Junaidi. 2017. Pengaruh Interaksi Macam Pupuk Kandang dan Dosis Terhadap Parameter-Parameter Pertumbuhan dan Hasil Tanaman Padi. Jurnal Agrinika. Volume: 1 No: 2. 
Kurniasari, A. M. Adisyahputra dan R. Rosmon. 2010. Pengaruh Kekeringan Pada Tanah Beragam NaCl Terhadap Pertumbuhan Tanaman Nilam. Skripsi. Tidak dipublikasikan. Jurusan Biologi. Fakultas MIPA. Universitas Indonesia, Jakarta.

Lakitan, B. 2011. Dasar-Dasar Fisiologi Tumbuhan. Penerbit Raja Grafindo Persada, Jakarta.

Lestari, E.P. 2015. Pengaruh Pemberian Air Limbah Tahu Terhadap Pertumbuhan Tanaman Sawi Caisim (Brassica juncea L.). Skripsi. Tidak dipublikasikan. Universitas Sanata Dharma, Yogyakarta.

Myrna, N.E.F. 2006. Hasil Tanaman Jagung Pada Berbagai Dosis dan Cara Pemupukan N Pada Lahan Dengan Sistem Olah Tanah Minimum. Jurnal Agronomi. Volume: 9 No: 1.

Novizan. 2002. Petunjuk Pemupukan Efektif. Penerbit Agromedia, Jakarta.

Nursyamsi. D. 2006. Kabutuhan Hara Kalium Tanaman Kedelai di Tanah Ultisol. Jurnal Ilmu Tanah dan Lingkungan. Volume: 6 No: 2

Putra, A. D, MMB Damanik dan H.Hanum. 2015. Aplikasi Pupuk urea dan pupuk kandang kambing untuk meningkatkan N-Total Pada tanah inceptisol kwala bekala dan kaitannya terhadap pertumbuhan tanaman Jagung (Zea mays L.). Jurnal Online Agroteknologi. Vol 3.

Rukmi. 2010. Pengaruh Pemupukan Kalium dan Fosfat Terhadap Pertumbuhan dan Hasil Kedelai. Jurnal Universitas Muria. Volume: 2 No: 2

Rosman, R. Setyono, dan Suheni. 2004. Pengaruh Naungan Dan Pupuk Fosfor Terhadap Pertumbuhan Dan Produksi Nilam (Pogostemon Cablin Benth.). Universitas Djuanda.

Rotama., K. G, Gunawan T, dan Sukemi I. S. 2015. Pertumbuhan Bibit Kakao (Theobroma Cacao L.) yang ditanam Pada Beberapa Medium Tumbuh dengan Pemberian Pupuk Organik Cair. JOM Faperta. Volume: 2 No: 1

Safitri, M. D, Kus Hendarto, Kuswanta Futas Hidayat dan Sunyoto. 2017. Pengaruh Dosis Pupuk Kandang Kambing dan Pupuk Hayati Terhadap Pertumbuhan dan Hasil Jagung (Zea Mays L.) Jurnal Agrotek Tropika. Volume: 5 No: 2.

Sarsini, Hary. 2008. Pengaruh Pengolahan Tanah dan Pupuk N Serta Pupuk Kandang Terhadap Serapan Ca, S dan Kualitas Hasil Kacang Tanah 
(Arachis Hypogaea L.) Pada Tanah Alfisol. Skripsi. Tidak dipublikasikan. Fakultas Pertanian. Universitas Sebelas Maret, Surakarta.

Setiono dan Azwarta. 2020. Pengaruh Pemberian Pupuk Kandang Terhadap pertumbuhan dan Hasil Tanaman Jagung Manis (Zea mays L.). Jurnal Sains Agro. Volume: 5 No: 2.

Sidemen, I Nengah, I Dewa Nyoman Raka dan Putu Bagus Udiyana. 2017. Pengaruh Jenis Pupuk Organik Terhadap Pertumbuhan Tanaman Bayam (Amaranthus sp.) Pada Tanah Tegalan Asal Daerah Kumbu Karangasem. Jurnal Agrimeta. Volume: 7 No: 13.

Subekti, H. F. D . 2005. Pengaruh Jenis Pupuk kandang dan Konsentrasi Pupuk Pelengkap Cair terhadap Pertumbuhan Bibit Karet (Hevea brasilliensis Muell. Arg). Klon IRR 39 Asal Stum Mata Tidur dipolybag. Skripsi. Tidak dipublikasikan. Fakultas Pertanian Universitas Muhammadiyah Palembang, Palembang.

Tadjudin. E. , Amran J dan Heni. J. 2016. Pengaruh Kombinasi Jarak Tanam dan Jenis Pupuk Kandang Terhadap Pertumbuhan dan Hasil Tanaman Jagung (Zea Mays L.) Jurnal Kultivar Bisma. Universitas Swadaya Gunungjati. Volume: 4 No: 1.

Trivana., L, Adhitya Yudha Pradhana, dan Alfred Pahala Manambangtua. 2017. Optimalisasi Waktu Pengomposan Pupuk Kandang dari Kotoran Kambing dan Debu Sabut Kelapa Dengan Bioaktivator EM4. Jurnal Sains dan Teknologi Lingkungan. Volume: 9 No: 1.

Wijanarko, A., Sudaryono, dan Sutarno. 2007. Karakteristik Sifat Kimia dan Fisika Tanah Alfisol di Jawa Timur dan Jawa Tengah. Jurnal IPTEK Tanaman Pangan. Volume: 2 No: 2.

Yuanita. V. R. 2016. Respon Pupuk Kandang Kambing dan Pupuk NPK Pada Pertumbuhan dan Hasil Tanaman Terung Hijau (Solanum Melongena L.). Jurnal Viabel Pertanain. Volume: 1 No: 1.

Zubaidah, Y Rafli, M. 2007. Aktifitas Pemupukan Fosfor Pada Lahan Sawah Dengan Kandungan P Sedang. Jurnal Solum. Volume: 4 No: 1. 